\title{
The Peluit Heat Utilization for Low-Rank Coal Upgrading
}

\author{
Sriyono Sriyono a, ${ }^{\text {, }}$, Rahayu Kusumastuti ${ }^{\text {a }}$, Djati H. Salimy ${ }^{a}$, Ign. Djoko Irianto ${ }^{\text {a }}$, Sofia L. Butarbutar ${ }^{\text {a }}$, \\ Abdul Hafid ${ }^{a}$, Topan Setiadipura a, Geni R. Sunaryo ${ }^{\text {a }}$, Endiah P. Hastuti ${ }^{\text {a }}$, M. Subekti ${ }^{\text {a }}$ \\ ${ }^{a}$ Center for Nuclear Reactor Technology and Safety, BATAN, Building No.80, Puspiptek Area,Tangerang Selatan, Banten, 17433, Indonesia \\ Corresponding author: *sriyono@batan.go.id
}

\begin{abstract}
BATAN is developing a power reactor called the Peluit. In addition to electrical generation, the reactor's heat is used for cogeneration. A possible cogeneration process is coal upgrading. Indonesia holds 161,0 billion tons of coal reserves, $60 \%$ of which is low-rank coal with a moisture content of over $25 \%$. During combustion, the low-rank coal produces extremely low heat and high $\mathrm{CO}_{2}$ emissions. To increase the coal quality, a drying process is needed. Peluit is designed to generate superheated steam on the secondary side with temperatures above $500^{\circ} \mathrm{C}$. It can be used for coal upgrading. Peluit can be built side by side with a coal-fired plant and provide it with good quality coal. Various studies on coal drying using conventional heat have been done and found it ineffective and inefficient. This research aims to determine the total amount of dried coal producible by utilizing Peluit superheated steam. The ChemCAD software package is used for modeling and simulation. Superheated steam is assumed at $500^{\circ} \mathrm{C}, 15 \mathrm{~kg} / \mathrm{s}$, and $5 \mathrm{bars}$. The dry coal combustion heat value is assumed to increase from $4840 \mathrm{kcal} / \mathrm{kg}$ to around $6170 \mathrm{kcal} / \mathrm{kg}$. The temperature of the rotary drum is maintained at $150^{\circ} \mathrm{C}$ to prevent spontaneous dried coal combustion, and the moisture content is set at $10 \%$. Approximately 600 tons/day of low-rank coal can be dried with this method, and its moisture content is reduced from $40 \%$ to $10 \%$.
\end{abstract}

Keywords - Low-rank coal; moisture; upgrading; heat; cogeneration; Peluit.

Manuscript received 24 Mar. 2021; revised 30 May 2021; accepted 27 Aug. 2021. Date of publication 31 Dec. 2021. IJASEIT is licensed under a Creative Commons Attribution-Share Alike 4.0 International License.

\section{INTRODUCTION}

National Nuclear Energy Agency/Badan Tenaga Nuklir Nasional (BATAN) is currently developing two conceptual designs of power reactors called Pembangkit Listrik dan Uap Untuk Industri (Peluit) and Reaktor Daya Eksperimental (RDE). Both of these reactors were pebble bed gas-cooled reactors (HTGR) [1]. RDE is $10 \mathrm{MW}_{\text {th }}$ and Peluit is $150 \mathrm{MW}_{\text {th }}$ of thermal power. Peluit is designed by joint-lab cooperation between BATAN and Tsinghua University of Beijing, China. It is a pebble-bed type reactor with indirect cycle power conversion [2]. Pebble bed type reactor was chosen due to its strong passive safety features [3]. Peluit is expected to be a prototype for the future Indonesian commercial nuclear reactor to fulfill the large electricity demand [4]. The pebblebed type is also flexible in terms of different fuel cycles, including the standard $\mathrm{U}, \mathrm{Th}$, or Pu cycle [5]. The reactor core inlet and outlet temperatures are $\sim 250^{\circ} \mathrm{C}$ and $\sim 750^{\circ} \mathrm{C}$, respectively [6]. The thermal heat generated in the core is circulated by a helium gas blower to the steam generator for electricity generation and a heat utilization plant via an intermediate heat exchanger (IHX) [7]. The use of a steam generator or IHX ensures that the safety of the installation is maintained due to the possible of water ingress into the primary coolant [8]. The Peluit secondary coolant is water after it flows into steam generator/IHX, dry steam is produced, and at turbine and generator, this dry steam generates electricity. The steam discharged from the steam turbine could be condensed and recycled into the steam generation system [9]

HTGR including Peluit offers many advantages for industrial applications [10]. Peluit can implement cogeneration processes, including several industrial process applications i.e. desalination, enhance oil recovery, coal upgrading, coal gasification/ liquefaction, hydrogen production, etc. [11], [12].

Indonesia holds 161,0 billion tons of coal reserves, 2-3 percent of the world's reserves, but $60 \%$ of them are medium and low-rank coal (lignite) with more than $25 \%$ of high moisture content [13]. The high water content in low-quality coal could affect its utilization [14], including resulting in high $\mathrm{CO}_{2}$ emissions during firing [15], low combustion efficiency, probable spontaneous combustion in storage facility [16] and increased shipping costs [17]. Due to their characteristics, low-rank coals also have low calorific values that make it difficult for Indonesian fired-coal stations to 
utilize [17]. During coal burned in a power station, it produces very low heat and high $\mathrm{CO}_{2}$ emissions [13]. Therefore, to increase the coal quality, the drying process is needed [17]. Peluit is designed to produce dry steam on the secondary side with temperatures above $500^{\circ} \mathrm{C}$. This temperature can be used for coal upgrading with a large capacity. To support a coalfired power plant that requires a continuous supply of coal, small nuclear power reactors such as Peluit can be built side by side at the same location so the coal-fired power plant gets a good quality of coal [14].

This research aims to prescribe the amount of dry coal that can be generated by using the secondary dry steam of Peluit. ChemCAD software is used to simulate it to achieve this objective, and the calculation results were compared to other literature study results. The simulation output is $7-10 \%$ of coal moisture content within the temperature inside of the rotary drum below $150^{\circ} \mathrm{C}$. Various literature sources of scientific publications are used to compare data and information on coal drying philosophies.

\section{MAteriAls AND METHOD}

\section{A. The Conceptual Design of Peluit Cogeneration}

HTGR is one of the nuclear power reactors that is justified to be the most promising choice to meet future energy needs. It has higher thermal efficiency than a light water reactor (LWR). HTGR can be used for heat generation for supporting the cogeneration process and industrial electricity supply [2]. The cogeneration process includes heat supply for the chemical industry, steel [12], coal gasification/liquefaction [11], oil mine [18], coal drying, hydrogen production, and desalination. Based on this fact, Peluit can be used as a supporting power in industrial areas in Indonesia through cogeneration conceptual design for coal drying of Peluit (See Figure 1).

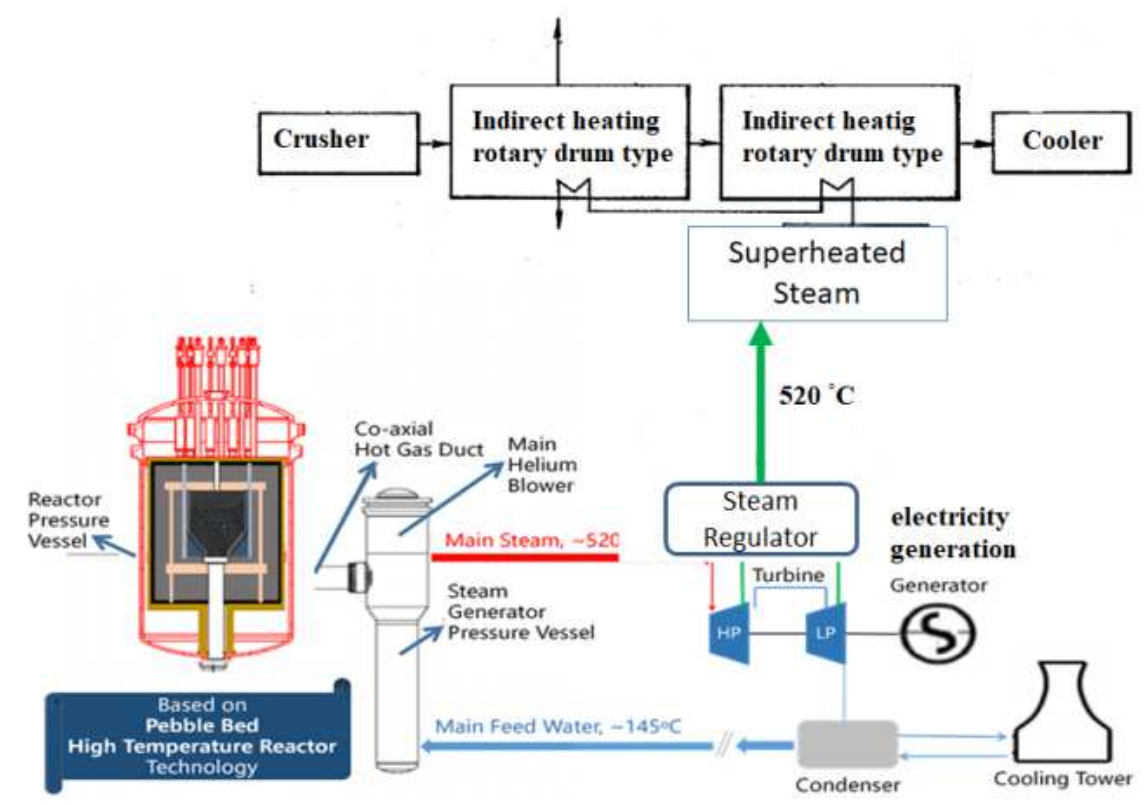

Fig. 1 The cogeneration conceptual design for coal drying of Peluit .[1]

The Peluit uses pebble fuel, it has an indirect cycle energy conversion, and the thermal power is $150 \mathrm{MW}$, equal to 60 MW electrical power. Peluit is designed and could be used for mainly electricity generation, and the other function is to supply the heat for cogeneration processes i.e., hydrogen generation, coal drying, coal gasification/liquefaction, enhanced oil recovery, waste treatment, desalination, and other industrial processes [19]. The cogeneration conceptual design for the coal drying of Peluit is shown in Figure 1.

In Peluit, the heat is transferred from primary to secondary coolant through a steam generator (SG) [4]. The secondary coolant is good quality water with a certain specification. The dry steam in the secondary coolant moves towards a single shaft turbine with an electric generator to generate electricity. The kinetic energy of dry steam is converted into electrical energy by an electric generator. The condenser condenses the turbine steam outlet, and the water formed is returned to the secondary coolant for recirculation [20]. The technical specification of Peluit is shown in Table 1.
TABLE I

The Peluit TeChNicAl SPeCIFICATION

\begin{tabular}{|c|c|c|}
\hline Reactor Core & Nominal & Units \\
\hline Height & 650 & $\mathrm{~cm}$ \\
\hline Diameter & 300 & $\mathrm{~cm}$ \\
\hline The void above the core & 30 & $\mathrm{~cm}$ \\
\hline The thickness of the top reflector & 150 & $\mathrm{~cm}$ \\
\hline The thickness of the side reflector & 115 & $\mathrm{~cm}$ \\
\hline $\begin{array}{l}\text { The thickness of the bottom } \\
\text { reflector }\end{array}$ & 150 & $\mathrm{~cm}$ \\
\hline Fuel loading scheme & \multicolumn{2}{|c|}{ Multipass } \\
\hline Inactive core fuel element & 247.813 & FE \\
\hline The Core residence time & 1043 & EFPD \\
\hline Fuel element discharged & 3565 & $\mathrm{FE} /$ day \\
\hline Fresh FE per day & $\sim 238$ & $\mathrm{FE} /$ day \\
\hline Graphite balls per day & --- & $\begin{array}{c}\mathrm{FE} / \mathrm{day} \\
\mathrm{MWd} / \mathrm{Kg}-\end{array}$ \\
\hline Average Discharge BU & 87.69 & $\mathrm{HM}$ \\
\hline Avg. power density & 3.26 & $\mathrm{~W} / \mathrm{cm}^{3}$ \\
\hline Max. power density & 5.12 & $\mathrm{~W} / \mathrm{cm}^{3}$ \\
\hline
\end{tabular}




\begin{tabular}{lcc}
\hline $\begin{array}{l}\text { Max. power per fuel ball } \\
\text { Primary Coolant }\end{array}$ & 1.447 & $\mathrm{~kW} / \mathrm{FE}$ \\
$\begin{array}{l}\text { Primary coolant mass flow rate } \\
\text { Reactor pressure operation }\end{array}$ & 57 & $\mathrm{Kg} / \mathrm{s}$ \\
$\begin{array}{l}\text { Inlet temperature of the core } \\
\text { coolant }\end{array}$ & 7 & $\mathrm{MPa}$ \\
$\begin{array}{l}\text { The outlet temperature of the core } \\
\text { coolant }\end{array}$ & 250 & ${ }^{\circ} \mathrm{C}$ \\
$\begin{array}{l}\text { Max. Fuel Temp. under normal } \\
\text { operation }\end{array}$ & 750 & ${ }^{\circ} \mathrm{C}$ \\
$\begin{array}{l}\text { Avg. Fuel Temp under normal } \\
\text { operation }\end{array}$ & 903.7 & ${ }^{\circ} \mathrm{C}$ \\
$\begin{array}{l}\text { Max. Fuel temp. under DLOFC } \\
\text { Time to max. fuel temp. under }\end{array}$ & 540.8 & ${ }^{\circ} \mathrm{C}$ \\
$\begin{array}{l}\text { DLOFC } \\
\text { Power Conversion System }\end{array}$ & 1450 & ${ }^{\circ} \mathrm{C}$ \\
$\begin{array}{l}\text { Media } \\
\text { Flow rate at nominal operation }\end{array}$ & 30 & $\mathrm{Hours}$ \\
$\begin{array}{l}\text { SG outlet pressure } \\
\text { SG outlet temperature }\end{array}$ & 59.5 & $\mathrm{Kg} / \mathrm{s}$ \\
$\begin{array}{l}\text { Feedwater Temperature (input to } \\
\text { SG) }\end{array}$ & 14 & $\mathrm{MPa}$ \\
$\begin{array}{l}\text { Feed water Pressure (input to SG) } \\
\text { Feed water mass flow rate }\end{array}$ & 200 & ${ }^{\circ} \mathrm{C}$ \\
\hline
\end{tabular}

\section{B. Low-Rank Coal Resources in Indonesia}

In terms of fulfillment of energy demands, coal plays a key role in supporting global economic development. At present, $27 \%$ of the world's primary energy needs and $41 \%$ of the world's electricity comes from coal. In some countries, the percentage of coal-fired power plants is much higher, for example, in China, 79\%, South Africa, 93\%, Poland, 92\%, and Australia, $77 \%$. In Indonesia, coal-fired power stations supply almost $61 \%$ of national energy demand. The use of coal to fuel power plants in Indonesia is also increasing and leads to low rank or lignite coal which has a calorific value of $+4,200 \mathrm{kcal} / \mathrm{kg}$ (gross as received or GAR) [21].

The existing coal power plant in Indonesia cannot use all available lignite because some lignite has a calorific value of less than 4,200 kcal $/ \mathrm{kg}$. Coal drying technology has been developed in the world since the 1920s. The first project was in Austria. The Flessner process was developed to reduce the water content of low-rank coal using superheated steam. At present, many coal drying technologies have been developed and based on the water phase that comes out of coal during the process itself.

Coal has many benefits, including raw material for chemical synthesis and as a power plant fuel [22]. Coal quality is determined at its initial moisture content. Coal is dried to increase its calorific value, thereby increasing boiler combustion efficiency. Coal drying technology is categorized into evaporative and non-evaporative technologies. In evaporative technology, water is removed from coal in the gas phase, whereas in non-evaporative technology, the water is released from coal in a liquid phase due to the use of high pressure. Most of coal drying technology is evaporative technology, such as upgraded brown coal (UBC) technology [14], binderless coal briquetting (BCB), coal upgraded briquettes (CUB), and others [14]. UBC coal drying is shown in Figure 2. The non-evaporative technology is hydrothermal technology such as continuous hydrothermal dewatering (CHTD). Tools used for coal drying also vary, such as rotary dryers, flash dryers, fluidized bed dryers, slurry evaporators, autoclaves, and hydraulic presses.

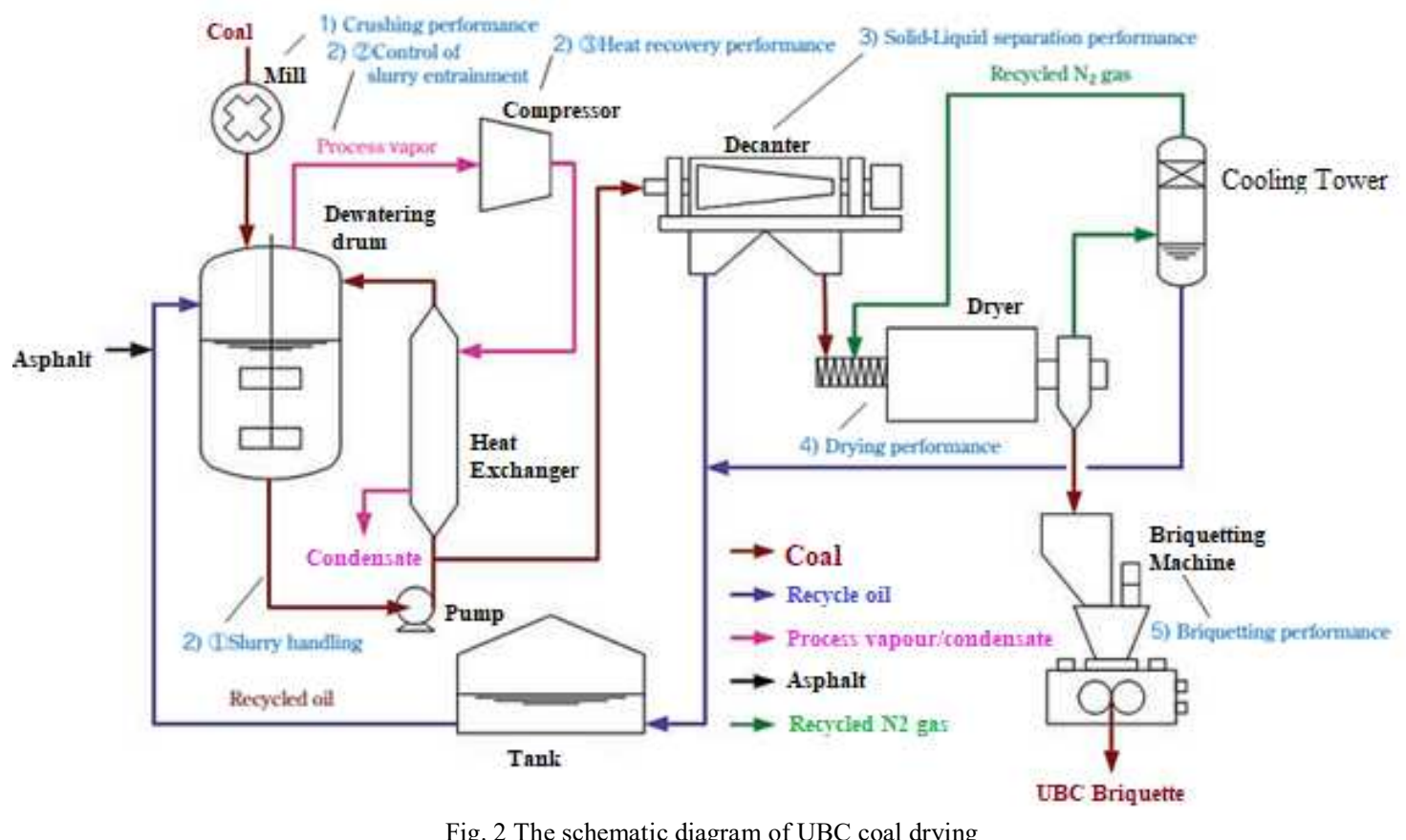

Fig. 2 The schematic diagram of UBC coal drying

In line with the issue of global warming, coal drying technology has been developed in several countries that can reduce total $\mathrm{CO}_{2}$ emissions from power plants, such as coal drying technology using heat waste energy from a power plant and nuclear cogeneration systems. For example, the heat waste in a power plant is heat energy in the exhaust stream or energy in hot water that could lead to the cooling process at the cooling station. Cogeneration or combined heat and power (CHP) power plants are power plants designed to produce 
steam for industrial purposes in addition to steam for power generation turbines.

The utilization of waste heat for coal drying was developed in America by the Great River Energy Company, in Germany by RWE, and in Australia by Monash University. A cogeneration coal drying system was developed in Japan and has been implemented in Indonesia. The companies named Sojitz and Tsukishima Kikai have implemented coal drying with energy from low-pressure steam from the Suralaya and Labuhan power plants using a rotary dryer equipped with pipes to flow steam (steam tube rotary dryer or STD). In STD there is no direct contact between coal and steam to be recycled directly to the boiler. There was a reduction of $\mathrm{CO}_{2}$ emissions by 250,000 tons/year after the technology was applied to the coal-fired station with a capacity of $700 \mathrm{MW}$, and coal moisture content before and after the drying process are $43.6 \%$ and $10 \%$, respectively.

\section{The ChemCAD Model and Simulation}

The energy conversion system of Peluit has been modeled using ChemCAD, as seen in Figure 3. Helium as primary system and secondary is water/steam. The helium mass flow rate is $57 \mathrm{~kg} / \mathrm{s}$, and 70 bars. The core inlet temperature is $250{ }^{\circ} \mathrm{C}$ and $750^{\circ} \mathrm{C}$ at the outlet. The superheated steam at secondary coolant can be utilized for electricity and otherwise for cogeneration.

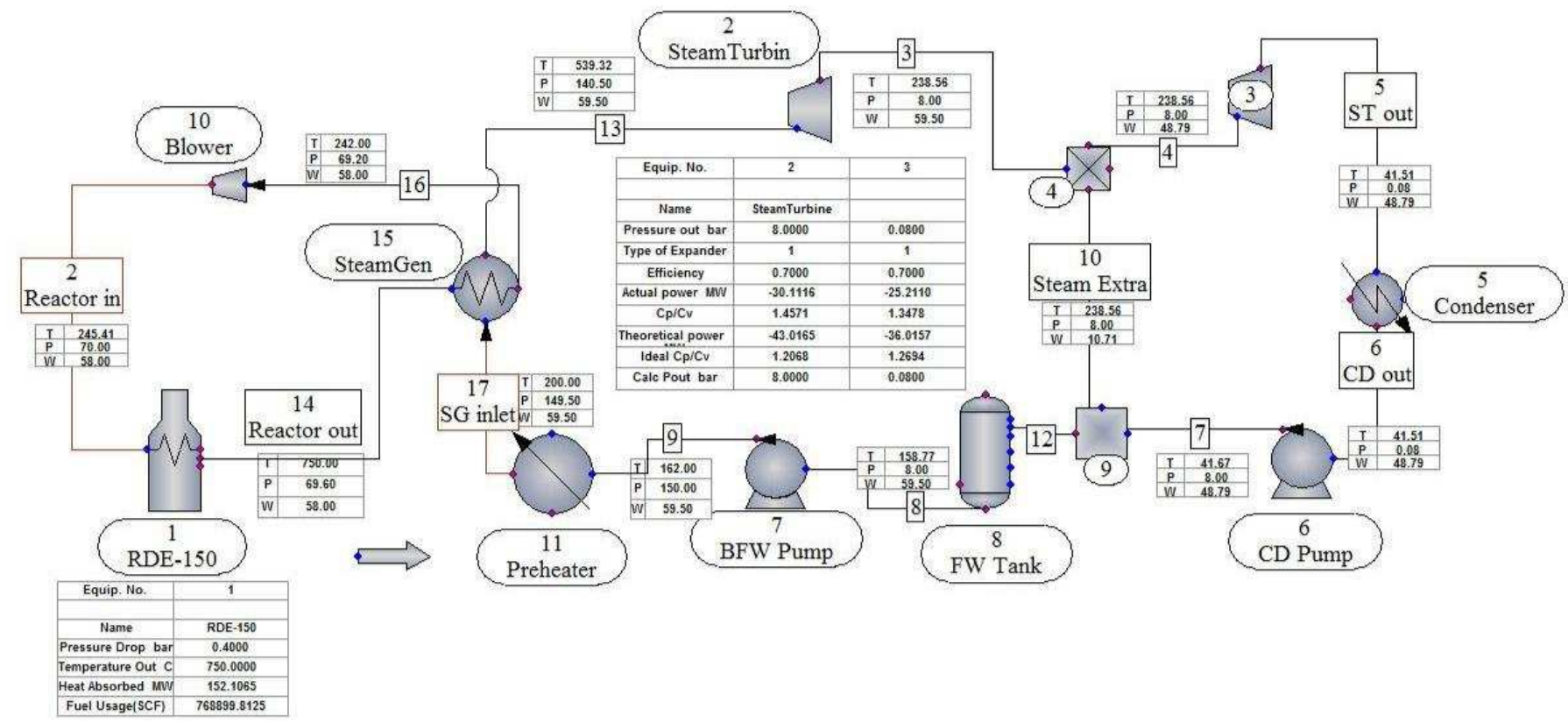

Fig. 3 The ChemCAD simulation of the power conversion system of Peluit

This research assumes that the coal upgrading process uses a direct heating rotary dryer with a co-current flow using steam output from low-pressure turbines with a temperature of $500{ }^{\circ} \mathrm{C}$. The steam mass flow rate used is assumed $15 \mathrm{~kg} / \mathrm{s}$ (about $25 \%$ of the total mass flow rate) as a drying media. There is direct contact between the dry steam and the coal to be dried in the direct heating coal drying. The direct heating method is chosen because it is the simplest and most economical unit. The simulation is targeted to produce coal with a total moisture content of $7-10 \%$ and a calorific value of 5000-6000 kcal/ $\mathrm{kg}$ (GAR) [13]. To achieve this dry coal production, the temperature of the dried coal is maintained at less than $150^{\circ} \mathrm{C}$ in the solid dryer to prevent spontaneous combustion. The low-rank coal feed to the direct rotary drum varies from $100 \mathrm{~kg} / \mathrm{h}$ to $600 \mathrm{~kg} / \mathrm{h}$.

The simulations performed in this study used a solid dryer unit, as seen in Figure 4, with an input of low-rank coal with moisture content ranging from $20 \%$ to $45 \%$. The solid dryer is working as a rotary drum, direct contact heating. Direct heating is used due to its simple technology and economic aspect. Moisture content in the dried coal product is $7-10 \%$; the maximum temperature set up in the dryer is $150{ }^{\circ} \mathrm{C}$. The cyclone was installed before wet coal was fed into the solid dryer. The cyclone was separated from the fine coal dust. The expander was used to reduce the superheated steam.

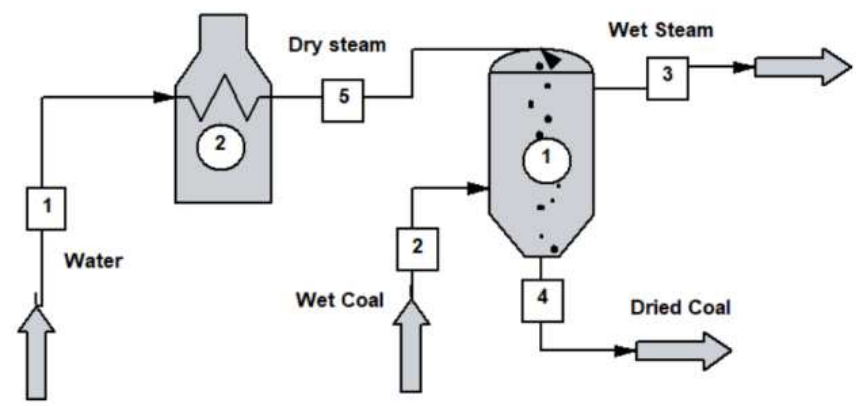

Fig. 4 Solid dryer model for coal dewatering

\section{RESULTS AND DISCUSSION}

\section{A. Energy Needs for Coal Drying}

The solid dryer unit operation in ChemCAD is one component can be used for coal drying simulation. Drying is the removal of water from wet coal to form dried coal by vaporization. The mechanism of coal drying is categorized into indirect contact (conduction), direct (convection), 
dielectric or microwave (radio frequency), and radiant (radiation) drying. Heat and mass transfer are crucial aspects of the drying process. Heat is transferred to the coal to evaporate moisture, and mass is transferred as a vapor into the surrounding gas. The solid dryer is working as a rotary drum, direct contact heating. Direct heating is used due to its simple technology and economic aspect. Moisture content in the dried coal product is $10 \%$, with the maximum temperature set up in the dryer being $150{ }^{\circ} \mathrm{C}$. The temperature must be maintained at this setpoint to avoid coal combustion.

Figure 5 shows the relationship of moisture content of coal with a calorific value that the coal itself could generate. The reducing moisture content in the coal could increase the carbon ratio content in the coal and automatically increase its calorific value. In general, the moisture content of coal needs for the coal-fired station is less than $20-23 \%$. Therefore, the assumption of $10 \%$ moisture content for coal drying is sufficient to meet these needs. For low-rank coal such as lignite, less than $8 \%$ moisture content could easily affect spontaneous combustion. Dry steam, which is fed into a solid dryer, has a mass flow rate of $15 \mathrm{~kg} / \mathrm{s}$ a quarter of the total mass flow rate in the secondary coolant, a temperature of $500{ }^{\circ} \mathrm{C}$, and the pressure after being decreased 5 bars. To mitigate the coal dust, a cyclone was installed at the input stream of a solid dryer. The cyclone is set up to separate the fine and coarse dust lower than 50 microns in diameter. The coal is set as a solid carbon material as a coarse dust particle.

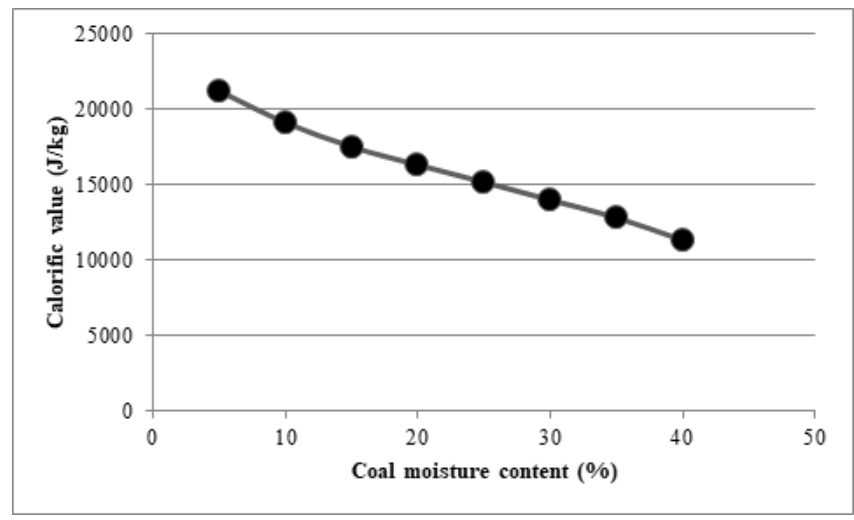

Fig. 5 The coal moisture and its calorific value changes

The energy needed for the evaporation process from lignite coal $\left(\mathrm{Q}_{\mathrm{t}}\right)$ includes the energy needed to raise the temperature of the coal $\left(\mathrm{Q}_{1}\right)$, the energy needed to raise the temperature of the water $\left(\mathrm{Q}_{2}\right)$, and the energy needed to evaporate water at boiling point $\left(\mathrm{Q}_{3}\right)$. Thus, the total energy needed to dry coal $\left(Q_{t}\right)$ is defined as follows:

$$
\begin{aligned}
& \mathrm{Q}_{\mathrm{t}}=\mathrm{Q}_{1}+\mathrm{Q}_{2}+\mathrm{Q}_{3} \\
& \mathrm{Q}_{1}=\mathrm{m}_{1} \mathrm{Cp}_{1} \mathrm{dT} \\
& \mathrm{Q}_{2}=\mathrm{m}_{2} \mathrm{Cp}_{2} \mathrm{dT} \\
& \mathrm{Q}_{3}=\mathrm{m}_{2}^{1} .
\end{aligned}
$$

Where: $\mathrm{m}_{1}$ is raw coal mass flow rate, $\mathrm{Cp}_{1}$ is coal heat capacity $\left(0.33 \mathrm{kcal} / \mathrm{kg}^{\circ} \mathrm{C}\right), \mathrm{m}_{2}$ is mass of water, $\mathrm{Cp}_{2}$ is heat capacity of water $\left(1 \mathrm{kcal} / \mathrm{kg} .{ }^{\circ} \mathrm{C}\right)$, and 1 is the latent heat of water $(542.18 \mathrm{kcal} / \mathrm{kg})$. The total energy requirement $\left(\mathrm{Q}_{\mathrm{t}}\right)$ to evaporate water in ideal conditions at $100 \%$ of efficiency is $799 \mathrm{cal} / \mathrm{g}$ of water [13].

Figure 6 shows the relationship between superheated steam mass flow rate and energy generated for coal drying processes from the secondary coolant of Peluit. Some assumptions are considered, i.e., the superheated steam temperature outlet of the steam generator is $500^{\circ} \mathrm{C}$, the bypass flow in the secondary coolant is varied from $5 \mathrm{~kg} / \mathrm{s}$ to $15 \mathrm{~kg} / \mathrm{s}$, the moisture/water evaporation temperature in the coal is $100^{\circ} \mathrm{C}$, the heat latent of water is $542.18 \mathrm{kcal} / \mathrm{kg}$.

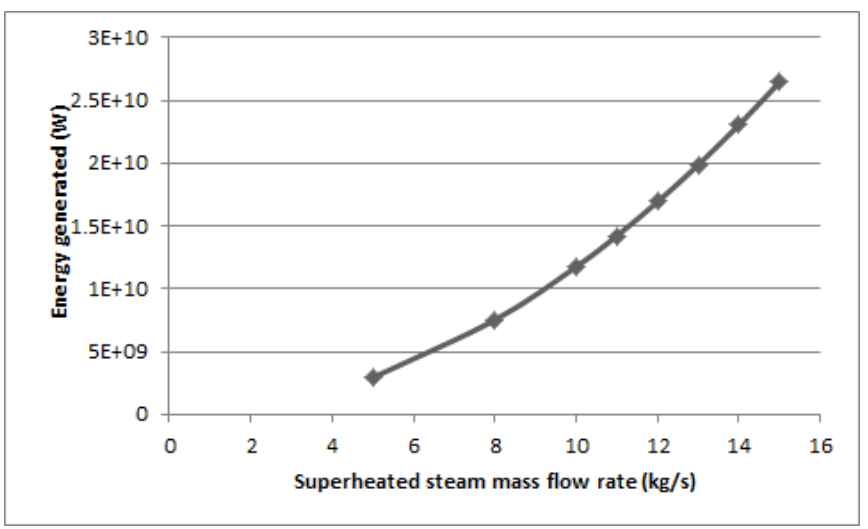

Fig. 6 The correlation between superheated steam mass flow rate and energy generated for coal drying processes.

The larger of bypass flow rate at secondary coolant results the greater heat energy that can be used for the drying process. Superheated steam bypass flow rate is a key parameter for coal upgrading, and it determines the total amount of low-rank coal that can be dried. However, there is a limit of bypass flow that does not interfere with the reactor electrical generation. It is a maximum of a quarter of the main secondary flow rate used for coal drying. Almost all heat energy is directly transferred to the coal to evaporate the moisture by direct heating.

In ChemCAD simulation, at first, it is assumed that stream no. 2 is wet (low-rank) coal, a temperature of $30^{\circ} \mathrm{C}$, moisture content of $40 \%$, with a mass flow rate of $10 \mathrm{~kg} / \mathrm{s}$. Stream no. 5 is superheated steam flow from the reactor core at $15 \mathrm{~kg} / \mathrm{s}$, $500{ }^{\circ} \mathrm{C}$. It is also assumed that the dry coal product still has $10 \%$ of moisture/water. Simulation results show that the amount of dry coal produced is $624428.0747 \mathrm{~kg}$ per day. The amount of dry coal could increase if the wet coal feed has less water content, as seen in Figure 7.

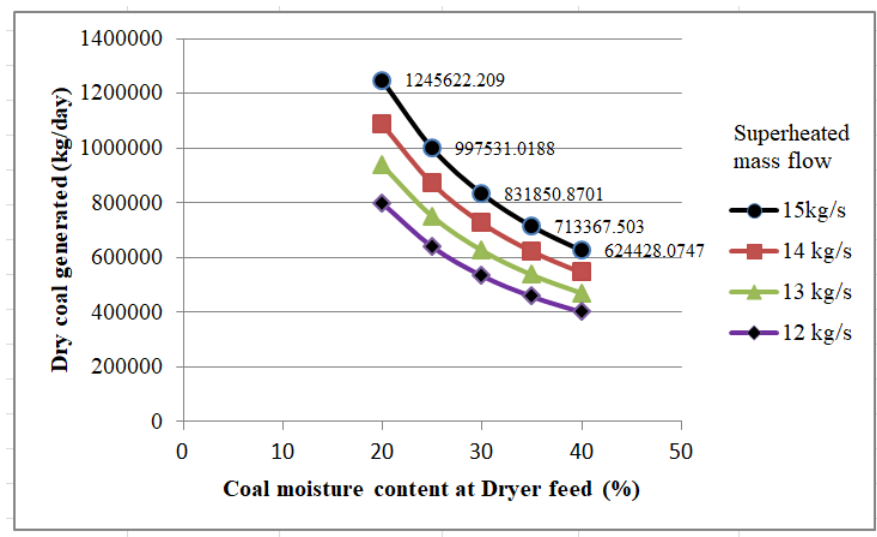

Fig. 7 The correlation between coal moisture content and dried coal generated by using a quarter superheated steam mass flow rate at secondary coolant of Peluit

The superheated steam mass flow rate changes affected to amount of dry coal production and is shown further in Table 
2. By varying the superheated steam flow rate of $12 \mathrm{~kg} / \mathrm{s}, 13$ $\mathrm{kg} / \mathrm{s}$ and $14 \mathrm{~kg} / \mathrm{s}$, the dry coal obtained is less than at mass flow rate of $15 \mathrm{~kg} / \mathrm{s}$.

TABLE II

Dry Coal Production from Superheated Steam of Peluit

\begin{tabular}{ccc}
\hline $\begin{array}{c}\text { Superheated } \\
\text { steam mass } \\
\begin{array}{c}\text { flow } \\
\text { rate/stream } \\
\text { no.5 (kg/s) }\end{array}\end{array}$ & $\begin{array}{c}\text { Low-rank coal } \\
\text { moisture content } \\
\text { at feed/stream no. }\end{array}$ & $\begin{array}{c}\text { Dry coal production/ } \\
\text { stream no.4 (kg/day) }\end{array}$ \\
\hline 12 & $\mathbf{2}$ (\%) & \\
& 20 & $399,633.9678$ \\
& 25 & $456,555.2019$ \\
& 30 & $532,384.5569$ \\
13 & 35 & $638,419.8520$ \\
& 40 & $797,198.214$ \\
& 20 & $935,600.6818$ \\
& 25 & $749,256.6319$ \\
14 & 30 & $624,812.4314$ \\
& 35 & $535,818.2578$ \\
& 40 & $469,014.8650$ \\
& 20 & $108,5075.347$ \\
15 & 25 & $868,960.3541$ \\
& 30 & $724,634.5358$ \\
& 35 & $621,422.3582$ \\
& 40 & $543,946.2340$ \\
& 20 & $124,5622.209$ \\
& 25 & $997,531.0188$ \\
& 30 & $831,850.8701$ \\
& 35 & $713,367.5030$ \\
& 40 & $624,428.0747$ \\
\hline
\end{tabular}

\section{B. Water Re-absorption in the Dry Coal}

One of the problems in drying the coal is the occurrence of water re-absorption by coal. Dried coal has a hydrophilic nature. Oxygen $\left(\mathrm{O}_{2}\right)$ in coal pores easily reacts with hydrogen $\left(\mathrm{H}_{2}\right)$ to form water $\left(\mathrm{H}_{2} \mathrm{O}\right)$, and it is simply contained in the coal matrix Water in coal is located in pores and easily attaches to the surface, which contains oxygen. There are three ways to prevent water from returning to the coal by closing the pores of the coal with additives, destroying the pores through grinding or heating, and drying the coal at a rather high temperature so that the oxygen function group is released from the coal. Although in the drying process to be studied (GRE technology and Sotitz \& TSK technology) the temperature is low and does not use additives to close the coal pores, the absorption of moist water by dry coal is expected to be difficult because the product is directly utilized at the power plant. It takes a long time (3-7 days) for water to be reabsorbed until it reaches equilibrium moisture, and a maximum of only $30 \%$ of moist water could be reabsorbed by lignite after the drying process.

Low-quality coal has high water content. With the heating process, practically the water content in coal is drastically reduced. Thus, the quality of coal could be better if it is used as a fuel for a coal-fired power plant. The combustion process could be more efficient, clean, and environmentally friendly [23]. Even so, this technology still has a few weaknesses. The process of heating coal could leave large pore holes, so it is riskier to burn if in contact with air. Because it is highly recommended, the process of direct heating / indirect heating should be placed close to the power plant with an ideal distance of about 40 meters so that coal that has been heated can be directly used.
Blending low-calorie coal with high calories is another way to produce quality coal with a calorific value according to the design of the power plant. Blending coal can be done by mixing several types of coal in the stockpile, in the conveyor belt, in the hopper, in the crusher, in the grinding machine, and others. The choice of blending method depends on the conditions at which the blending could take place, the capacity of the blending facility, the required blending accuracy, and the type of user (end-user) of the blending product. Although the application of blending technology is estimated to have lower investment costs compared to coal drying technology, the blending process requires coal with higher calorific value or coal at a higher price.

The drying low-rank coal method with a temperature above the boiling point of water is used to dry the coal without big affected due to high temperatures. Thus, this process has the advantage of maintaining the coal matrix integrity and a small amount of thermal oxidation. Various drying technologies, such as steam tube dryers, are used for the process. The obstacle is that the large latent heat could increase energy requirements, and the bad impact is the occurrence of spontaneous combustion.

Some power plants use a rotary dryer equipped with pipes to flow steam (steam tube rotary dryer or STD) for coal drying. In STD, there is no direct contact between coal and steam so that steam can be recycled directly to the boiler. Based on the study results, there could be a reduction of $\mathrm{CO}_{2}$ emissions by 250,000 tons/year if the technology is applied to the coal-fired station (PLTU) with a capacity of $700 \mathrm{MW}$ and coal moisture content before and after the drying process is $43.6 \%$ and $10 \%$, respectively

\section{CONCLUSION}

Coal drying research has been carried out using a solid dryer model. The superheated steam of Peluit is flown to the dryer at $500{ }^{\circ} \mathrm{C}, 15 \mathrm{~kg} / \mathrm{s}$, and 10 bars. A $10 \mathrm{~kg} / \mathrm{s}$ of low-rank coal is fed to the dryer generated 600 tons per day of dry coal with $10 \%$ of moisture content. Drying coal is hydrophilic. Oxygen in coal pores easily reacts with hydrogen to form water. Water in coal is located in pores and easily attaches to the surface, which contains oxygen. There are three ways to prevent water from returning to the coal by closing the pores of the coal with additives, destroying the pores through grinding or heating, and drying the coal at a rather high temperature so that the oxygen function group is released from the coal.

\section{ACKNOWLEDGMENT}

The authors thank the Ministry of Research and Higher Education for funding this cogeneration research through Insinas Ristek-BRIN. In addition, this research is also supported by DIPA PTKRN BATAN of the fiscal year 2021.

\section{REFERENCES}

[1] H. J. Lab, "Conceptual Design of 150MWt Pebble Bed Type High Temperature Reactor," 2019.

[2] Sriyono et al., "The turbine heat waste of RDE for desalination laboratory plant," J. Phys. Conf. Ser., vol. 1772, no. 1, 2021, doi: 10.1088/1742-6596/1772/1/012036.

[3] R. Kusumastuti, S. Sriyono, H. Tjahjono, T. Setiadipura, and M. Pancoko, "The RCCS thermal analysis during the station blackout 
accident of RDE," J. Phys. Conf. Ser., vol. 1772, no. 1, 2021, doi: 10.1088/1742-6596/1772/1/012037.

[4] M. Pancoko, A. Nugroho, D. Priambodo, and T. Setiadipura, "Design Study of a Straight Tube Bundle Steam Generator for Reaktor Daya Eksperimental," vol. 9, no. 5, pp. 531-540, 2018.

[5] T. Setiadipura, S. Bakhri, and G. R. Sunaryo, "Study on characteristic of temperature coefficient of reactivity for Plutonium core of Pebbled Bed Reactor," J. Phys. Conf. Ser., vol. 962, no. 1, pp. 2-11, 2018, doi: 10.1088/1742-6596/962/1/012058.

[6] S. Sriyono et al., "Temperature profile analysis on cryogenic activated carbon column of helium purification testing facility," AIP Conf. Proc., vol. 2180, no. December 2019, doi: 10.1063/1.5135555.

[7] I. D. Irianto, S. Dibyo, S. Sriyono, D. H. Salimy, R. Kusumastuti, and M. Pancoko, "Performance analysis of cogeneration energy conversion system design for RDE," IOP Conf. Ser. Mater. Sci. Eng., vol. 830, no. 3, 2020, doi: 10.1088/1757-899X/830/3/032092.

[8] P. Ferrão, J. Fournier, and O. Le, "Fueling Scheme for the Indonesian Experimental on District Heating and Cooling Power Reactor (10 MWth Pebble-Bed HTGR)," Energy Procedia, vol. 131, pp. 69-76, 2017, doi: 10.1016/j.egypro.2017.09.477.

[9] I. D. Irianto et al., "Effect of Superheated Steam Pressure on the Performance of RDE Energy Conversion System," J. Phys. Conf. Ser., vol. 1198 , no. 2, 2019, doi: 10.1088/1742-6596/1198/2/022045.

[10] D. H. Salimy et al., "The assessment of nuclear hydrogen cogeneration system application for steel industry," AIP Conf. Proc., vol. 2180, no. December 2019, doi: 10.1063/1.5135547.

[11] N. Nurhadi, M. A. Andriansyah Efendi, and S. Rianda, "The utilization of fixed bed coal gasification by-products to produce combustible gas by auto-thermal process," Int. J. Adv. Sci. Eng. Inf. Technol., vol. 7, no. 5, pp. 1964-1969, 2017, doi: 10.18517/ijaseit.7.5.2104.

[12] S. Djati H Salimy, "The assessment of nuclear hydrogen cogeneration system application for steel industry," J. Phys. Conf. Ser., no. December 2019, doi: 10.1063/1.5135547.

[13] D. Y. Miftahul Huda, "The Influence of Coal Feed Rate on the Effectivity of Coal Drying Process," J. Teknol. Miner. dan Batubara, vol. 11, no. Im, pp. 18-28, 2015.

[14] B. D. Afrah, B. Sajjakulnukit, and M. D. Bustan, "Product competitiveness of Upgrading Brown Coal (UBC) process in
Indonesia," Int. J. Adv. Sci. Eng. Inf. Technol., vol. 7, no. 4, pp. 1289 1295, 2017, doi: 10.18517/ijaseit.7.4.2488.

[15] M. Faizal, "Utilization biomass and coal mixture to produce alternative solid fuel for reducing emission of greenhouse gas," Int. J. Adv. Sci. Eng. Inf. Technol., vol. 7, no. 3, pp. 950-956, 2017, doi: 10.18517/ijaseit.7.3.2474

[16] J. Fan, G. Wang, and J. Zhang, "Study on spontaneous combustion tendency of coals with different metamorphic grade at low moisture content based on TPO-DSC," Energies, vol. 12, no. 20, 2019, doi: 10.3390/en12203890.

[17] I. Bizzy, R. Sipahutar, E. Ibrahim, and M. Faizal, "Determining of drying characteristics for South Sumatera low-rank coal using solar and laboratory scaled oven," Int. J. Adv. Sci. Eng. Inf. Technol., vol. 7, no. 6, pp. 1998-2003, 2017, doi: 10.18517/ijaseit.7.6.2006.

[18] D. H. Salimy and H. Sriyono Sriyono, Abdul, "The assessment of nuclear hydrogen cogeneration system (NHCS) for CO2 conversion to urea fertilizer," Malaysian J. Fundam. Appl. Sci., vol. 16, no. 2, pp. 135-138, 2020.

[19] G. Chen et al., "Distribution of trace elements during coal gasification : The effect of upgrading method," J. Clean. Prod., vol. 190, no. 5, pp. 193-199, 2018, doi: 10.1016/j.jclepro.2018.04.077.

[20] M. Pancoko, A. Nugroho, D. Priambodo, and T. Setiadipura, "Design study of a straight tube bundle steam generator for Reaktor Daya Eksperimental," Int. J. Mech. Eng., vol. 9, no. 5, pp. 531-540, 2018.

[21] L. Luo, F. Li, and H. Wang, "The Influence of Coal Calorific Value on Power Plant Boiler Operation,” Environ. Sci. Eng., vol. 5, no. Ese, pp. 26-30, 2017.

[22] D. Pudasainee and R. Gupta, "Review on chemical upgrading of coal: Production processes, potential applications and recent developments,' Fuel Process. Technol., vol. 158, pp. 35-56, 2017, doi: 10.1016/j.fuproc.2016.12.010.

[23] D. Syafrini, M. F. Nurdin, Y. S. Sugandi, and A. Miko, "Rejuvenation of the Former Coal Mining Industry Area into a Heritage Site: A Solution to Overcome the Threat of Environmental and Social Problems," Int. J. Adv. Sci. Eng. Inf. Technol., vol. 10, no. 5, pp. 21112117, 2020, doi: 10.18517/ijaseit.10.5.10921. 